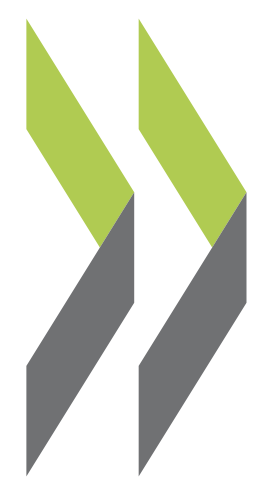

OECD Economics Department Working Papers No. 408

\title{
Russian Industrial
}

Restructuring: Trends in

$$
\text { Productivity, }
$$

\section{Rudiger Ahrend}

\section{Competitiveness and}

Comparative Advantage 
Organisation de Coopération et de Développement Economiques

Organisation for Economic Co-operation and Development

22-Oct-2004

ECONOMICS DEPARTMENT

English - Or. English

RUSSIAN INDUSTRIAL RESTRUCTURING: TRENDS IN PRODUCTIVITY, COMPETITIVENESS AND COMPARATIVE ADVANTAGE

ECONOMICS DEPARTMENT WORKING PAPERS NO. 408

by Rudiger Ahrend

All Economics Department Working Papers are now available through OECD's Internet Web site at http://www.oecd.org/eco 


\section{ABSTRACT/ RÉSUMÉ \\ Russian Industrial Restructuring: Trends in Productivity, Competitiveness and Comparative Advantage}

This article investigates issues related to industrial restructuring in Russia. Based on extensive sectoral data it examines, more particularly, levels and changes in labour productivity, unit labour costs and revealed comparative advantages for a large number of Russian industrial sectors. The main findings are the following. First, impressive increases in labour productivity have been achieved since 1997, especially during the post-crisis period. Secondly, this has been true for all major sectors, with the exception of those which are still predominantly state controlled or which suffer from strong state interference. Thirdly, there have been significant relative adjustments within the industrial sector, as labour productivity increased more in less productive sectors. Since the crisis, relative unit labour costs have also adjusted considerably, as less competitive sectors experienced relatively slower wage growth and larger labour force reductions. Fourthly, international competitiveness - as measured by revealed comparative advantage - remains limited to a small number of sectors that mainly produce primary commodities (particularly hydrocarbons) and energy intensive basic goods. And, finally, there has been a tendency for further specialisation in resource based exports in recent years.

JEL classification: L1, O52, P2, P31

Keywords: Russia; Transition; Industry; Sector; Productivity; Competitiveness; Revealed Comparative Advantage; Restructuring; Unit Labour Costs; Wages; Private Sector; State Control.

\section{La Restructuration du Secteur Industriel Russe: Évolutions de la Productivité, de la Compétitivité et de l'Avantage Comparatif}

Cet article étudie des questions relatives à la restructuration industrielle russe. Fondé sur une base étendue de données sectorielles, il examine plus spécifiquement les niveaux et les variations de la productivité du travail, des coûts unitaires de main d'œuvre et des avantages comparatifs révélés pour un grand nombre de secteurs industriels. Les principaux résultats sont les suivants. Premièrement, des augmentations importantes dans la productivité du travail ont été atteintes depuis 1997, notamment dans la période qui a suivi la crise. Deuxièmement, ceci a été vrai pour la totalité des principaux secteurs à l'exception de ceux qui sont encore majoritairement contrôlés par l'État ou qui souffrent d'une forte intervention de l'État. Troisièmement, il y a eu de significatifs ajustements relatifs dans le secteur industriel puisque l'augmentation de la productivité du travail a été plus importante dans les secteurs les moins productifs. Depuis la crise, les coûts unitaires relatifs de main d'œuvre se sont aussi considérablement ajustés, les secteurs les moins compétitifs ayant connu une croissance des salaires relativement plus lente et des réductions d'effectifs plus importantes. Quatrièmement, la compétitivité internationale - mesurée par les avantages comparatifs révélés - reste limité à un petit nombre de secteurs qui produisent majoritairement des matières premières (notamment des hydrocarbures) et des produits de base à forte intensité d'énergie. Finalement, ces dernières années, on observe une tendance à une spécialisation accrue en faveur des exportations de ressources naturelles.

JEL classification: L1, O52, P2, P31

Mots-clés: Russie; transition; industrie; secteur; productivité; compétitivité; avantage comparatif révélé; restructuration; coût unitaire de main d'œuvre; salaires; secteur privé; contrôle de l'État.

\section{Copyright OECD 2004}

Applications for permission to reproduce or translate all, or part of, this material should be made to: Head of Publications Service, OECD, 2 rue André Pascal, 75775 Paris Cédex 16, France 


\section{TABLE OF CONTENTS}

RUSSIAN INDUSTRIAL RESTRUCTURING: TRENDS IN PRODUCTIVITY, COMPETITIVENESS
AND COMPARATIVE ADVANTAGE...
Introduction
Labour productivity and unit labour costs.
Comparative advantage and disadvantage
Conclusion.




\title{
RUSSIAN INDUSTRIAL RESTRUCTURING: TRENDS IN PRODUCTIVITY, COMPETITIVENESS AND COMPARATIVE ADVANTAGE
}

\author{
by Rudiger Ahrend ${ }^{1}$
}

\section{Introduction}

The issue of industrial competitiveness is especially important for Russia. ${ }^{2}$ The coming years will see continued cost pressure on enterprises' inputs and further real exchange-rate appreciation, which will have to be matched by productivity increases. The 1998 financial crisis remains a vivid reminder of what can happen when productivity fails to increase in line with input costs or an appreciating exchange rate, rendering a country's industry increasingly uncompetitive. Industrial competitiveness, however, is not only a general, but also a structural issue in Russia. The dual structure of the economy ${ }^{3}$ means that productivity in a number of sectors, especially outside the natural resource industries, is still at levels that raise questions about their longer-term viability. It is therefore important to examine developments with respect to competitiveness closely by sector, particularly when assessing the development of non-resource industries. Industrial sectors can be compared with one another on the basis of such indicators as productivity levels, unit labour costs and revealed comparative advantages. This article looks specifically at how these measures have been changing over time in order to assess recent industrial performance. This analysis may also be helpful in understanding the current heated debate within Russia over the 'diversification' of the economy and in assessing various proposals to advance this diversification.

\section{Labour productivity and unit labour costs}

Productivity levels vary substantially among Russian industrial sectors. These differences are to some degree inherited from the Soviet past, ${ }^{4}$ since even then some sectors were much further than others from the productivity levels achieved in the advanced market economies. However, these differentials also reflect differences in restructuring and investment in recent years. Additionally, some sectors enjoy significant resource rents. These differences can be seen when looking, for example, at the output per

1. The author works in the Non-Member Economies Division of the OECD Economics Department. This paper draws on material originally produced for the fifth OECD Economic Survey of the Russian Federation published in July 2004, and the author is grateful to the many Russian and western officials, experts and businessmen, too numerous to list here by name, who discussed questions pertaining to industrial productivity and competitiveness with the Survey team The author is indebted to colleagues in the Economics Department for useful discussions, comments, and drafting suggestions, in particular Andrew Dean, Val Koromzay, Silvana Malle, Douglas Sutherland and William Tompson. Special thanks go to Corinne Chanteloup and Anne Legendre for technical assistance, as well as to Muriel Duluc and Lillie Kee for secretarial assistance. Responsibility for any errors of fact or judgement that remain in the paper rest, of course, entirely with the author.

2. While the question of competitiveness also arises in other sectors of the economy, we focus here on the industrial sector as it is by far the most open to external competition.

3. See Ahrend (1999), Ahrend (2004).

4. See Senik-Leygonie and Hughes (1992) and Ahrend (2002). 
employee $^{5}$ of what roughly constitute the 30 most important sectors ${ }^{6}$ in Russian industry (Figure 1). Bearing in mind that output per worker should naturally be higher in more capital-intensive sectors, the results nevertheless paint an interesting picture of the various industrial sectors. The sectors with the highest productivity levels are either those in which Russia has a comparative advantage and which contribute the bulk of Russian exports (e.g. gas, oil, metals), or those which cater to the internal market and which have received a large degree of FDI in recent years (e.g. tobacco, brewing). Unsurprisingly, these sectors also tend to be highly profitable (Figure A2). The sectors towards the bottom of the list tend to be those that are generally regarded as the most problematic and that are barely profitable, if profitable at all. ${ }^{7}$

Figure 1. Productivity : levels and changes in the $\mathbf{3 0}$ most important industrial sectors

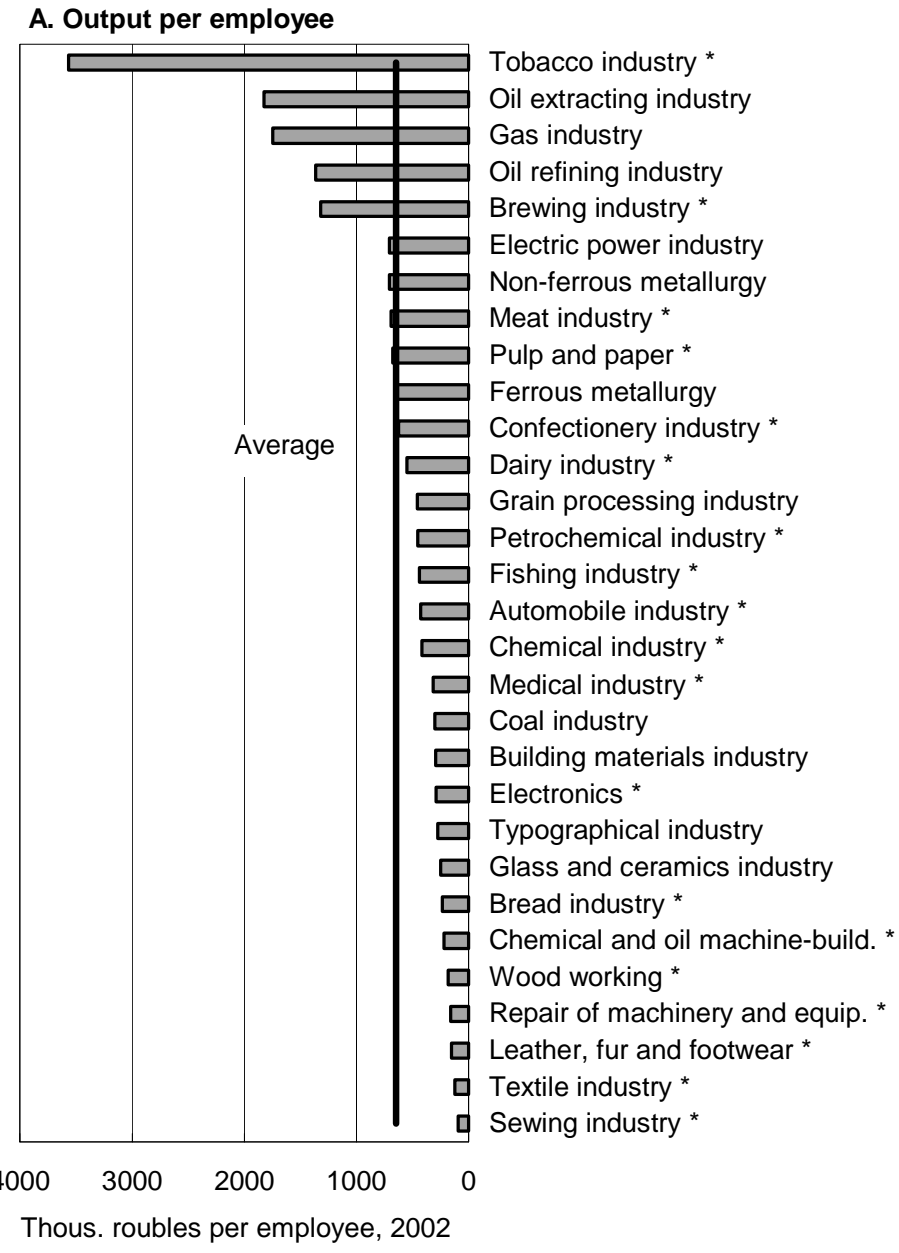

* Data on labour productivity for 1997-2002.

Source: Goskomstat and OECD calculations.
B. Labour productivity

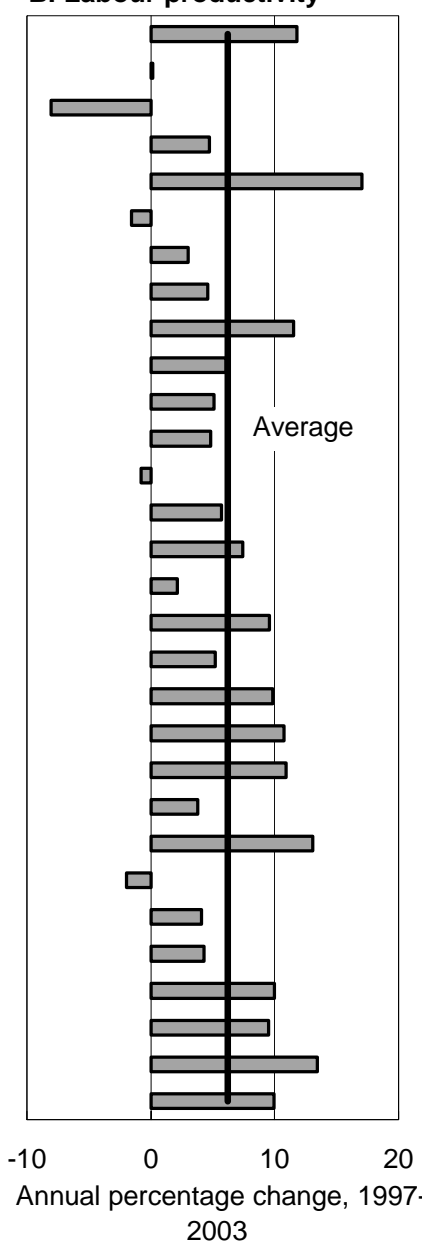

5. It would in principle be preferable to use value added per worker, but results are in any case qualitatively similar (see Figure A1). As data for value added are only available for a small number of sectors, output data are used instead.

6. The defence industrial sector is missing as data are unavailable.

7. See Figure A1. 
While the situation of many industrial sectors remains problematic, one must recognise the large improvements in productivity that have occurred in recent years. Industrial competitiveness, measured in terms of labour productivity, ${ }^{8}$ has been increasing strongly and steadily since 1997 (with the exception of 1998) at an average annual rate of around 8 per cent (Table 1; see also Tables A1 and A2). The performances of different sectors have varied widely, but, apart from a couple of inglorious exceptions (see below), there have been improvements in almost all of them. Moreover, there has been a tendency for these improvements to be larger in sectors with lower initial productivity (Figure 2). ${ }^{9}$ Unfortunately there were also a significant number of sectors where initial productivity was low and improved little, the most important of which is perhaps the automobile industry. With few exceptions, the largest increases in productivity were recorded by sectors that were among the least productive in 1997, including coal, textiles, leather, glass and ceramics, and electronics. Productivity in these sectors typically increased by a total of 60-90 per cent during 1997-2003 (Figure 1).

Table 1. Labour productivity

Annual percentage change

\begin{tabular}{|c|c|c|c|c|c|c|c|c|c|}
\hline & $\begin{array}{l}\text { Average } \\
1990-95\end{array}$ & 1996 & 1997 & 1998 & 1999 & 2000 & 2001 & 2002 & 2003 \\
\hline Total industry & -8.1 & 2.9 & 8.7 & 1.0 & 11.8 & 10.2 & 5.1 & 6.6 & 12.4 \\
\hline Electric power industry & -10.3 & -7.0 & -4.4 & -5.7 & -5.3 & -1.7 & -1.1 & -1.0 & 5.9 \\
\hline Fuel industry & -8.2 & -2.2 & 4.6 & 0.3 & 9.7 & 6.2 & -4.0 & -2.9 & 18.7 \\
\hline Ferrous metallurgy & -8.6 & -2.0 & 7.5 & -6.6 & 16.5 & 10.3 & -2.4 & 1.1 & 20.4 \\
\hline Non-ferrous metallurgy & -13.4 & -1.9 & 12.1 & 1.6 & 5.0 & 3.3 & 1.0 & -2.1 & 9.7 \\
\hline Chemical and petrochemical industry & -11.2 & -3.4 & 5.7 & -0.3 & 26.3 & 9.5 & 5.7 & 10.0 & 10.0 \\
\hline Machine-building and metal working & -8.5 & 4.5 & 11.1 & -1.5 & 20.6 & 19.5 & 8.5 & 7.4 & 14.6 \\
\hline Logging, woodworking, pulp-and-paper & -10.6 & -9.0 & 11.8 & 10.5 & 15.4 & 8.4 & 7.7 & 15.2 & 7.3 \\
\hline Building materials industry & -13.1 & -7.0 & 6.4 & 3.2 & 9.2 & 18.6 & 7.1 & 17.0 & 10.1 \\
\hline Light industry* & -20.1 & -8.3 & 10.4 & 2.0 & 15.2 & 23.0 & 9.5 & 4.0 & 12.4 \\
\hline Food industry & -11.8 & -2.8 & 1.5 & 5.0 & 0.9 & 10.5 & 7.4 & 7.9 & 6.0 \\
\hline
\end{tabular}

Source: Goskomstat and OECD calculations.

8. Russian growth has been mainly driven by total factor productivity (TFP) (Ahrend 2004). TFP would be a more exact way to measure industrial productivity developments. Using TFP on a sectoral level is, however, difficult in the Russian context, where the quality of data on sectoral capital stock is questionable and is in any case available for only a limited number of sectors. On the basis of enterprise-level data, it has been shown that TFP growth in Russian industry is closely linked to labour productivity growth. Moreover, results with respect to productivity growth are qualitatively similar when using production and value added data. While the use of value added data would be preferable, sectoral production based data are available for a much larger number of Russian sectors, and their quality is significantly better. Moreover, value added data are available only in current prices. Adequate deflators are unavailable, and the use of proxies reduces the quality of the data further. This article therefore concentrates on labour productivity (calculated on the basis of production data), as the most appropriate and robust measure available for a detailed analysis of sectoral trends.

9. This also holds for profitability. Productivity increased much more strongly in sectors where profits per employee were initially lower (see Figure A3). 
Figure 2. Initial productivity levels vs. productivity growth (by industrial sector)

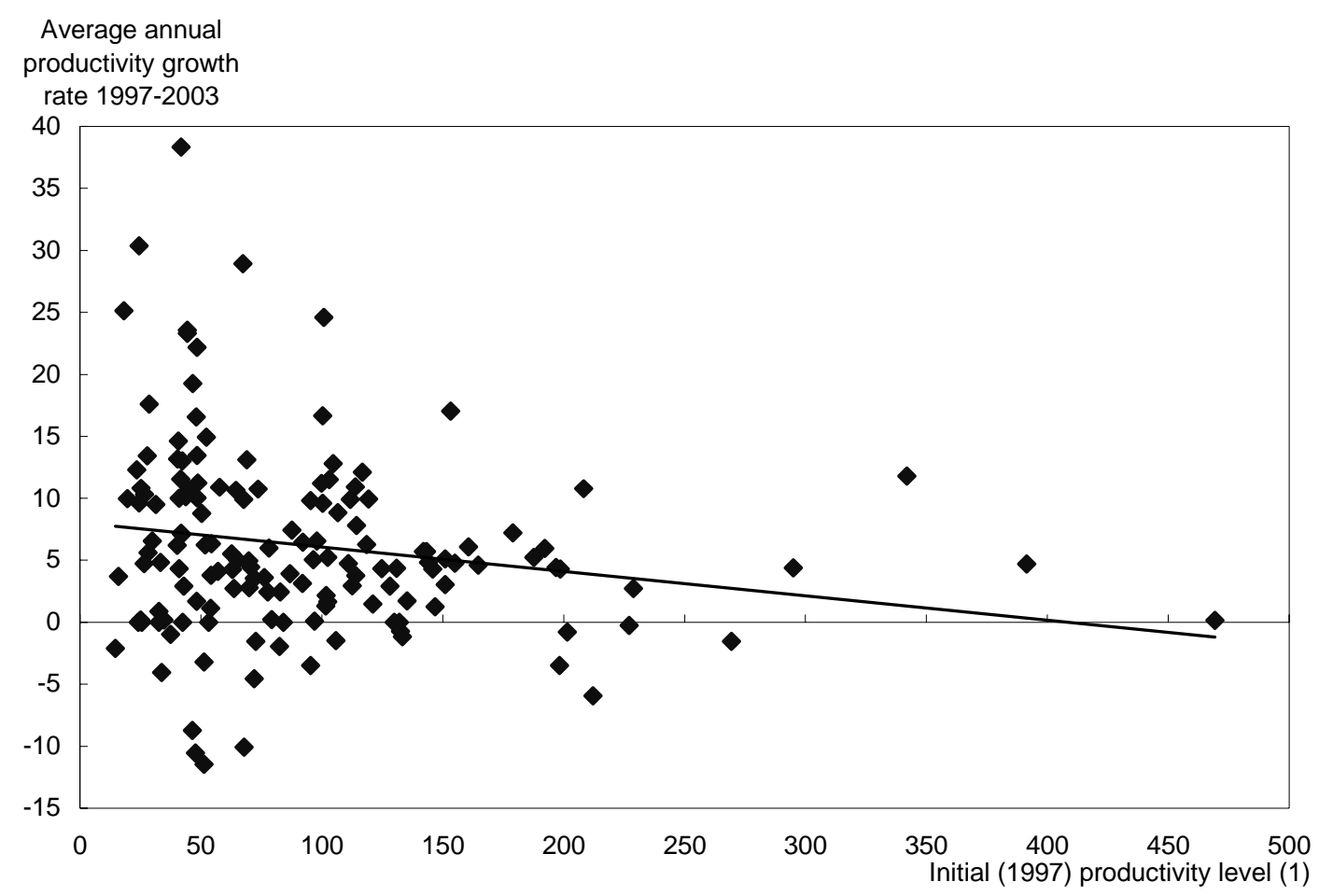

1. As measured by output per employee, thous. rubles, 1997.

Source: Goskomstat and OECD calculations.

Simplifying matters somewhat, one can roughly distinguish three phases since 1992 (Figure 3):

- In the period to 1998, enterprises were restructuring passively, in pursuit of short-term survival. In practice, this meant that enterprises tried to reduce employment as output fell. ${ }^{10}$ Prior to 1996 , the fall in output, however, far outstripped the reduction in employment, so that productivity levels fell.

- During 1999-2001, there was what may best be described as a 'recovery'. Productivity increased, but in aggregate this was mainly a by-product of increasing production, as enterprises profited from lower labour and non-labour costs in the wake of the rouble devaluation, as well as from generally abundant spare capacity. There were, of course, enterprises and sectors that restructured very deeply during this period, but it appears that most contented themselves with increasing output, and in aggregate there were no further reductions in industrial employment.

- By 2002, the easy gains from the devaluation were exhausted, as the real exchange rate had appreciated significantly and both labour and non-labour costs had increased. It was in 2002-03, therefore, that large numbers of enterprises finally began restructuring with a view to improving productivity. In 2002-03, industrial output grew relatively strongly while industrial employment fell. 
Figure 3. The composition of industrial productivity growth Annual percentage change

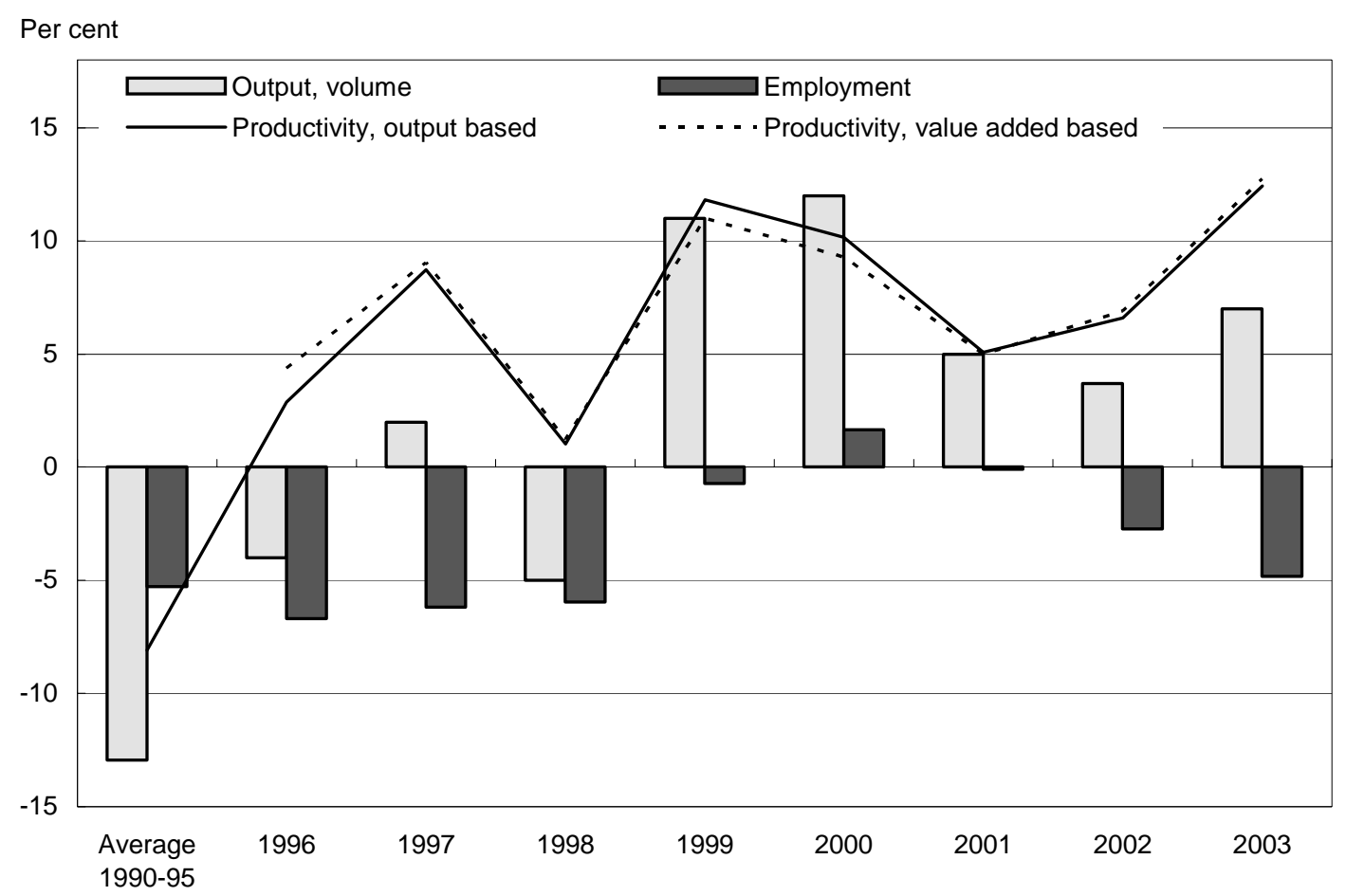

Source: Goskomstat and OECD calculations.

Large inter-sectoral differences are evident across the period and point to a significant reallocation of labour. While rising overall productivity in 1997-2003 was partly achieved by reducing overall employment levels, a significant number of sectors increased employment. ${ }^{11}$ In most cases, these increases took place in dynamic sectors with strongly rising output and increasing productivity (Figure 4). The few exceptions turn out to be sectors in which there is still significant direct state control or at least extensive state interference. The productivity performance of the grain-processing and bread sectors, as well as oil (before 1999) and electricity (until 2002), are uninspiring, while the gas sector is clearly at the bottom of the league.

11. For example, employment actually increased in roughly half of the 30 sectors referred to above. 
Figure 4. Employment and labour productivity 1997-2003

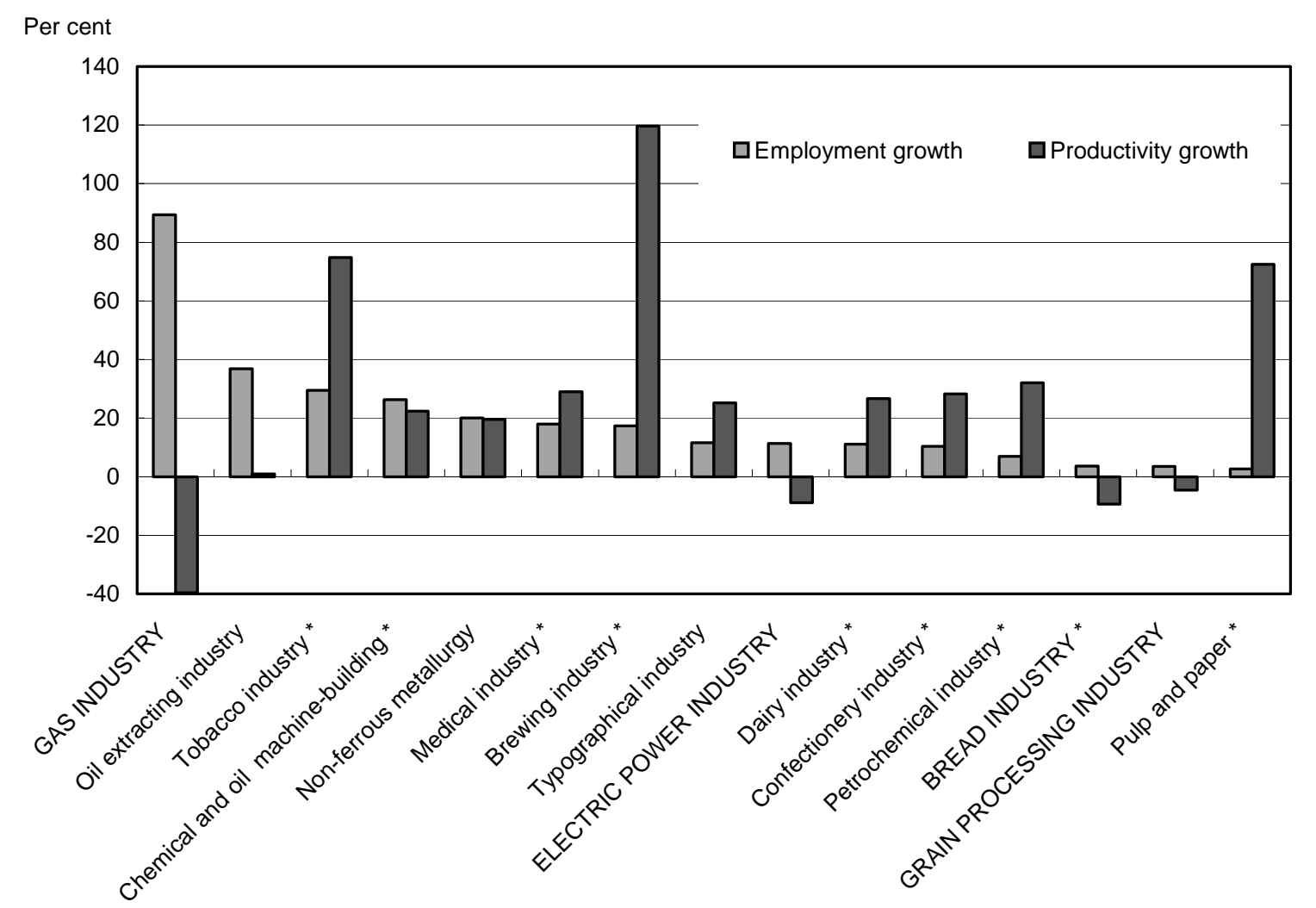

* Data for 1997-2002.

Source: Goskomstat and OECD calculations.

While increased productivity is an important benefit in itself, an assessment of industrial competitiveness must also look at indicators that take wage developments into account, such as unit labour costs (ULC). ${ }^{12}$ ULCs in Russian industry, which had fallen sharply after the 1998 devaluation, were still roughly 25 per cent below 1997 levels in 2003, despite the recovery of average wages to pre-crisis levels by 2002. This decrease in ULCs partly reflects the overall rise in productivity seen across almost all industrial sectors. In addition, there has been a tendency for labour-force reductions to be larger in sectors that had higher unit labour costs before the crisis, i.e. those that were a priori less competitive (see Figure A4a). However, increased competitiveness has also been achieved by better wage differentiation. While in the aftermath of the crisis wages in all sectors fell sharply, they subsequently recovered more slowly in less competitive sectors, i.e. those with high ULCs (see Figure A4b). As a result of these two developments, ULCs fell most in those sectors where they were highest before the crisis (Figure 5), and in almost all sectors unit labour costs in 2003 were below 1997 levels. The major exceptions were the electricity, oil and gas sectors. ULCs in the electricity industry in 2003 were roughly at 1997 levels. In the oil sector, they were up by 25 per cent, and in the gas industry, they more than doubled during

12. In calculating ULCs we use Russian wages measured in a hypothetical unit (UE) that consists of half a US Dollar and half a Euro. This yields a meaningful measure for the international price competitiveness of Russian industrial sectors that has the added advantage of being largely independent of swings in the Eurodollar exchange rate. 
1997-2003. ${ }^{13}$ It is striking that gas-sector wages, which were already almost four times the average for industry as a whole, increased at exceptionally high rates during this period, even as labour productivity in the gas sector fell by over 20 per cent while increasing almost everywhere else. This suggests large-scale rent-seeking by gas-sector insiders.

Figure 5. Unit labour costs by industry ${ }^{1}$

Relative to total industry, $1997=1$

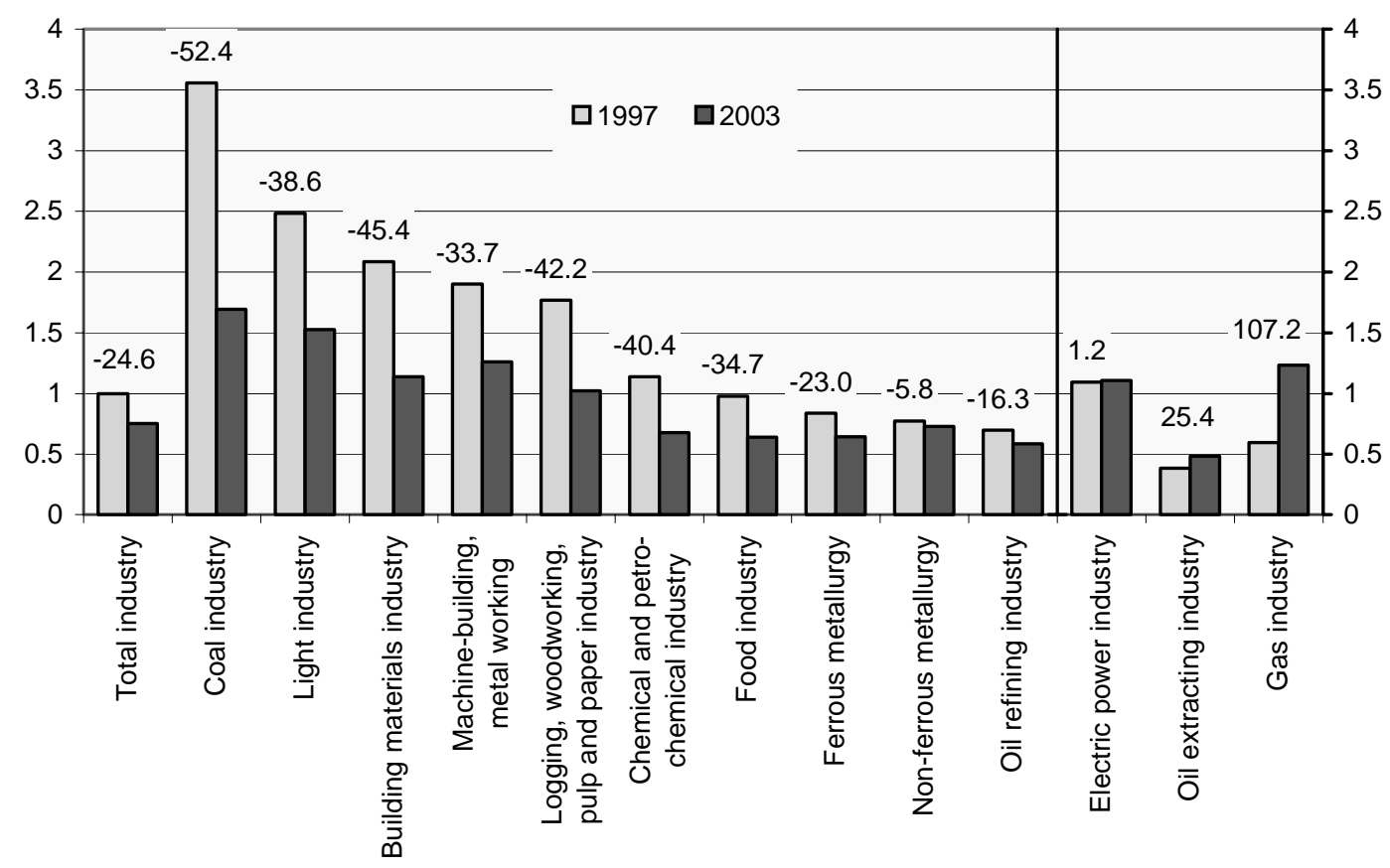

Note : The figures above columns represent percentage growth rate 1997-2003.

1. ULC calculated on the basis of data on sectoral employment, sectoral production volumes (in 2000 prices) and average wages (expressed in a hypothetical unit (UE) consisting of half a US Dollar and half a Euro).

Source: Goskomstat and OECD calculations.

13. Measured in the hypothetical unit (UE) described above. 
ECO/WKP(2004)31

\section{Comparative advantage and disadvantage}

While there have been important improvements both in the efficiency and competitiveness of most branches of Russian industry, few sectors have reached a degree of international competitiveness that would enable them to export on a significant scale. That, at least, is the picture that emerges when looking at Russia's revealed comparative advantage (RCA). ${ }^{14}$ Russia's major RCA is in hydrocarbons (oil, oil products and gas), together with some other resource-based (e.g. wood, pulp and paper) and energyintensive products (non-ferrous metals, steel, fertiliser). Moreover, the number of sectors in which Russia has some RCA, however small, is surprisingly short (see Table 2). ${ }^{15}$ The only 'machinery' sector where Russia has a small RCA is power-generating machinery and equipment. In all probability, Russia also has an RCA in arms, but official data are unavailable. On the other hand, Russia still has a major competitive disadvantage in such manufactured products as industrial machinery and equipment, electronic consumer goods, cars, and medicinal and pharmaceutical products. In addition it also has a substantial comparative disadvantage in meat production.

Overall, Russia has seen a further deepening of its major revealed comparative advantages and disadvantages between 1997 and 2003 (see Table A1.6). For example, Russia's RCA in oil, which was already huge in 1997, has further increased. The only other sectors in which Russia had some RCA in the past and which recorded noteworthy increases are the coal industry and the cork and wood sector. Positive changes in the RCAs of these two sectors have, however, been relatively small. At the same time, comparative disadvantages grew worse over the period in almost all the sectors in which Russia already had large negative RCAs. The further deterioration in the RCA figures for investment goods, reflecting a sharp increase in imports, does have a positive side, as it indicates that there has been a strong push for modernisation in parts of the industrial sector. It reflects badly, however, on the competitiveness of the Russian machinery and equipment sector. The deterioration in electronic consumer goods reflects increasing purchases of durables by the population and is thus a product of rising living standards. This outcome is not surprising, given that electronic consumer goods have never been a strong point of Russian industry. Deteriorating RCAs in meat production since 2000 likewise show indirectly that living standards have been increasing, but also, to the extent that they reflect rising imports, highlight the livestock sector's difficulty in competing with (often subsidised) imports. More worrying is the fact that the competitiveness of the automobile industry, which had improved somewhat after August 1998, has deteriorated and is now much worse than before the crisis. Finally it appears that the pharmaceuticals sector has also lost a lot of ground in recent years. There is also, however, a bright spot. The negative RCAs for cereals and cereals preparation have significantly improved and are now slightly positive, and there has also been some improvement in the negative RCAs for miscellaneous edible products and preparations. This indicates that the food industry's import competitiveness has been rising.

14. Following Neven (1995), revealed comparative advantages are computed as follows:

$$
R C A_{i}=\left(\frac{X_{i}}{\sum X_{k}}-\frac{M_{i}}{\sum M_{k}}\right) \cdot 100
$$

where $X_{i}$ and $M_{i}$ are, respectively, the exports and imports of product $i$. This indicator is bounded between 100 and (-100). The lower and upper limits of the index can be attained only in the (theoretical) case where there is complete trade specialisation and there are only two goods. Under real world circumstances, the value of the index rarely exceeds 10 (in modules). The higher the value of the index, the stronger the trade specialisation. The RCA index can be interpreted as a 'normalised' trade balance (i.e. given that the sum of the RCA indicators across sectors is equal to zero, the comparative advantages are in this way measured under the theoretical condition of a balanced trade). The value of this indicator is also related to the intensity of intra-industry trade. The stronger two-way trade, the lower specialisation and the closer to zero the index.

15. For more detail on trade structure and revealed comparative advantages, see also Tables A4 and A5. 
Table 2. Revealed comparative advantage (RCA)

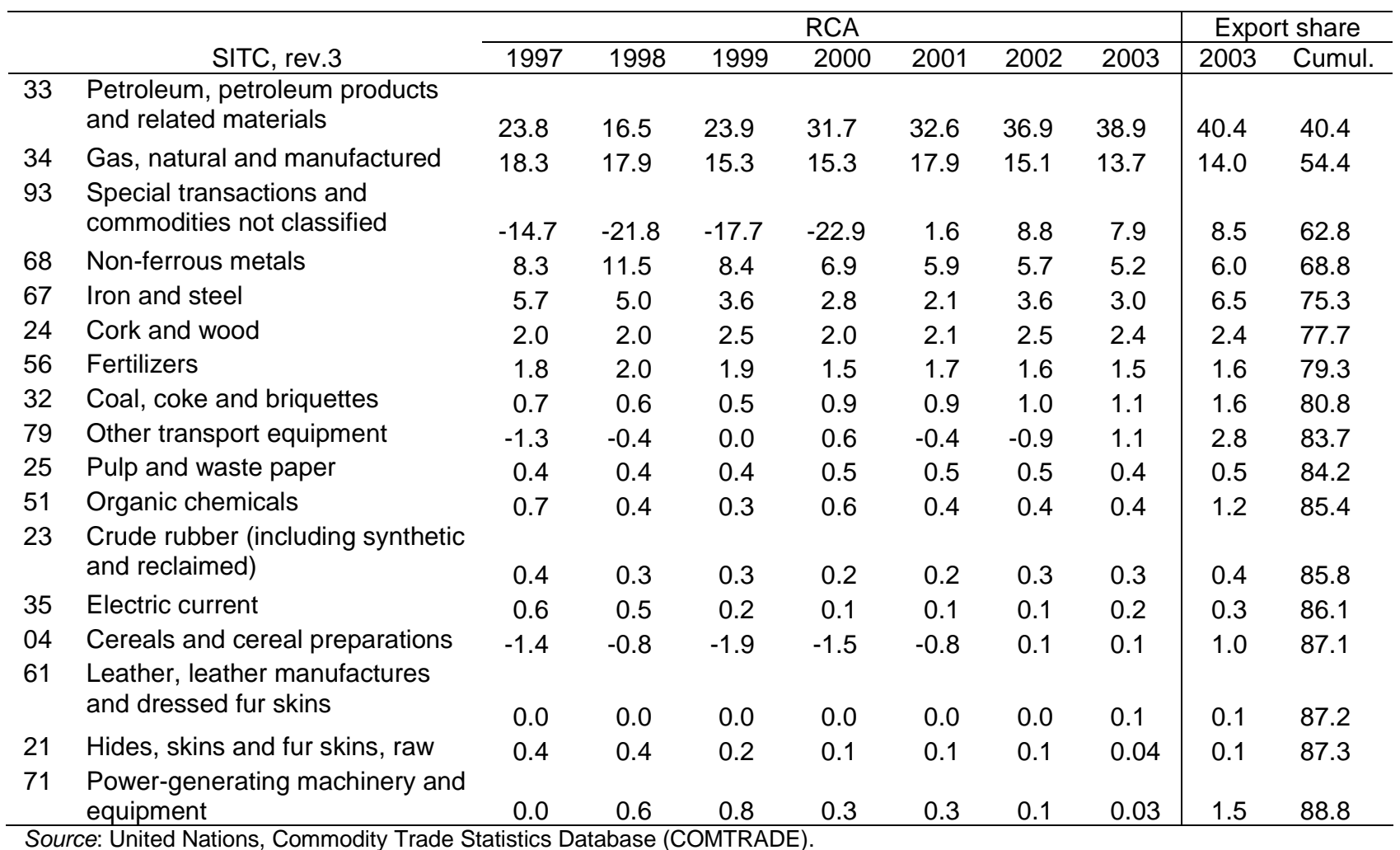


ECO/WKP(2004)31

Table 2. Revealed comparative advantage (RCA) (continued)

\begin{tabular}{|c|c|c|c|c|c|c|c|c|c|c|}
\hline \multirow{2}{*}{\multicolumn{2}{|c|}{ SITC, rev 3}} & \multicolumn{7}{|c|}{$\mathrm{RCA}$} & \multicolumn{2}{|c|}{ Import share } \\
\hline & & 1997 & 1998 & 1999 & 2000 & 2001 & 2002 & 2003 & 2003 & Cumul. \\
\hline 78 & Road vehicles & -2.5 & -2.0 & -1.2 & -1.5 & -3.7 & -4.4 & -6.6 & 7.5 & 7.5 \\
\hline 74 & General industrial machinery and & & & & & & & & & \\
\hline 77 & $\begin{array}{l}\text { equipment, and machine parts } \\
\text { Electrical machinery, apparatus and }\end{array}$ & -4.5 & -3.7 & -3.6 & -2.9 & -4.6 & -6.0 & -5.9 & 6.6 & 14.2 \\
\hline & $\begin{array}{l}\text { appliances, and electrical parts } \\
\text { thereof } \\
\text { Machinery specialized for particular }\end{array}$ & -2.2 & -2.1 & -1.7 & -1.7 & -3.5 & -4.7 & -5.3 & 5.9 & 20.0 \\
\hline $\begin{array}{l}72 \\
54\end{array}$ & $\begin{array}{l}\text { industries } \\
\text { Medicinal and pharmaceutical }\end{array}$ & -3.4 & -3.3 & -3.5 & -3.3 & -4.1 & -4.8 & -4.8 & 5.2 & 25.2 \\
\hline & produ & -2.5 & -2.2 & -2.1 & -2.8 & -4.4 & -3.7 & -4.4 & 4.5 & 29.7 \\
\hline 01 & Meat and meat preparations & -4.1 & -3.5 & -3.1 & -2.3 & -4.2 & -5.4 & -4.1 & 4.2 & 33.9 \\
\hline 05 & Vegetables and fruit & -2.7 & -2.4 & -2.5 & -2.6 & -2.9 & -3.5 & -3.9 & 4.0 & 37.9 \\
\hline 76 & $\begin{array}{l}\text { Telecommunications, sound- } \\
\text { recording, reproducing apparatus and } \\
\text { equipment }\end{array}$ & -2.1 & -1.8 & -1.6 & -1.8 & -3.3 & -4.1 & -3.4 & 3.6 & 41.5 \\
\hline 89 & Miscellaneous manufactured articles & -1.2 & -1.2 & -0.2 & -0.5 & -2.3 & -2.6 & -2.7 & 3.2 & 44.6 \\
\hline 55 & $\begin{array}{l}\text { Paper, paperboard and articles } \\
\text { thereof } \\
\text { Essential oils and resinoids and } \\
\text { perfume materials; toilet, polishing }\end{array}$ & -0.6 & -0.3 & -0.5 & -0.7 & -1.4 & -1.9 & -2.0 & 2.8 & 47.4 \\
\hline & & -1.1 & -1.0 & -0.7 & -0.8 & -1.4 & -1.9 & -2.0 & 2.2 & 49.6 \\
\hline 06 & $\begin{array}{l}\text { Sugars, sugar preparations and } \\
\text { honey } \\
\text { Coffee, tea, cocoa, spices, and }\end{array}$ & -1.9 & -2.2 & -3.1 & -1.9 & -3.2 & -2.3 & -1.9 & 2.0 & 51.6 \\
\hline & manufactures thereof & -1.2 & -1.2 & -1.4 & -1.3 & -1.7 & -2.0 & -1.8 & 1.9 & 53.5 \\
\hline 87 & $\begin{array}{l}\text { Professional, scientific and controlling } \\
\text { instruments and apparatus }\end{array}$ & -1.3 & -1.1 & -0.9 & -1.1 & -1.2 & -1.5 & -1.8 & 2.3 & 55.8 \\
\hline 69 & Manufactures of metals & -0.9 & -0.5 & 0.7 & 0.5 & -0.9 & -1.7 & -1.8 & 2.5 & 58.3 \\
\hline 11 & Beverages & -1.3 & -1.3 & -0.7 & -0.8 & -1.2 & -1.4 & -1.6 & 1.7 & 60.0 \\
\hline 65 & $\begin{array}{l}\text { Textile yarn, fabrics, made-up } \\
\text { articles, and related products }\end{array}$ & -0.7 & -0.6 & -1.0 & -1.2 & -1.6 & -1.4 & -1.6 & 1.9 & 61.9 \\
\hline 28 & Metalliferous ores and metal scrap & 0.0 & 0.9 & -0.9 & -2.5 & -2.8 & -2.1 & -1.6 & 2.5 & 64.4 \\
\hline 75 & $\begin{array}{l}\text { Office machines and automatic data- } \\
\text { processing machines }\end{array}$ & -07 & -05 & & & & 1 & 15 & 15 & \\
\hline 66 & Non-metallic mineral manufactures & -0.7 & $\begin{array}{r}-0.0 \\
1.4\end{array}$ & $\begin{array}{l}-0.0 \\
-0.6\end{array}$ & $\begin{array}{l}-0.0 \\
-0.7\end{array}$ & -1.1 & -1.4 & -1.4 & 1.7 & 67.6 \\
\hline
\end{tabular}

To some extent, the revealed comparative disadvantages of Russian non-mineral sectors reflect a still poor price-quality mix of products. Quality seems to be a particularly important issue in machine building and the chemical industry, whereas price is especially an issue in light industry ${ }^{16}$ (Table A7). Revealed comparative disadvantages may also reflect in part the problems facing enterprises in establishing themselves in new circumstances (e.g. in obtaining relevant licences, establishing brands, etc).

Overall, the most striking feature of Russia's RCAs is the increasingly narrow concentration of its revealed comparative advantage mentioned above. This suggests that the authorities' concern for economic diversification is well founded but at the same time highlights how difficult reducing Russia's reliance on natural resource exports will be. However, the analysis of trends in labour productivity and ULCs in

16. It should be noted that the Russian definition of 'light industry' covers only textiles, fur and leather goods. A large share of what in most countries would be classified as 'light industry' are categorised as machinebuilding in Russia. 
1992-2003 points to at least some grounds for cautious optimism. It is hardly surprising that there was little evidence of much restructuring prior to 1998. Macroeconomic conditions were highly unstable, ownership of assets was still unclear and often vigorously contested, and liquidity was severely constrained but budget constraints were soft. The focus on short-term survival was probably a rational course in the circumstances. However, the immediate post-crisis recovery demonstrated the ability of Russian industry to take advantage of the (necessarily temporary) increase in competitiveness brought about by the devaluation. This response was to a great extent the product of structural changes wrought in the $1990 \mathrm{~s} .{ }^{17}$ More impressive still has been the evidence of more aggressive restructuring as the effects of the devaluation have worn off.

One may reasonably hope that continued investment growth will lead gradually to the development of comparative advantage in areas other than mineral exports. This, however, will depend on the speed with which current handicaps can be overcome through further modernisation of production processes and products, better marketing, and more experience of international markets. An open economy, as well as increasing FDI levels, would be very helpful in this respect; while FDI is unlikely to become a major driver of growth any time soon, it could have - and indeed already has had - a significant impact on the fortunes of particular sectors. More active development of joint ventures in sectors like the automobile industry may be one way to facilitate the transfer of technology and managerial expertise to former state enterprises. By contrast, the productivity performance of sectors characterised by a high degree of state intervention in enterprise affairs provides a cautionary reminder of the dangers of attempting to force the pace of diversification by means of dirigiste industrial policies. Other structural reforms will also have a role to play. The transition to cost-reflective domestic energy prices will to some degree erode the (to some extent artificial) comparative advantages enjoyed by energy-intensive export sectors but will over time reward more energy-efficient production and thus lead to a more efficient allocation of productive resources. Banking and financial-sector reforms will also be important. One of Russia's major problems continues to be the lack of mechanisms for efficiently allocating investment resources across - and not merely within economic sectors. The banking system is weak and financial markets are small and illiquid ${ }^{18}$. Their development should facilitate not only increased investment overall but also the diversification of investment flows across sectors.

\section{Conclusion}

Recent years have seen impressive productivity increases in Russian industry, as well as a number of urgently needed relative adjustments among industrial sectors. In spite of these undoubtedly positive developments, international competitiveness has remained narrowly concentrated, mainly in resource based industries. Recent experience suggests that, while Russia has the potential to develop comparative advantage in other sectors, this is likely to remain a difficult and drawn out process.

\footnotetext{
17. OECD (2002:14).

18. OECD (2004), Chapter 5
} 
ECO/WKP(2004)31

\section{BIBLIOGRAPHY}

Ahrend, R. (1999), "Russia's Post-Stabilisation Economic Decline, its Crash, and Finally its Revival. Don't Just Blame the Corruption - It's the Exchange Rate, Stupid!", Russian Economic Trends, 8:3.

Ahrend, R. (2002), "Speed of Reform, Initial Conditions, Political Orientation, or What? Explaining Russian Regions' Economic Performance”, DELTA Working Paper 2002-10, February.

Ahrend, R. (2004), “Accounting for Russia's Post-Crisis Growth”, OECD Working Paper, September

Neven, D. (1995), “Trade Liberalization with Eastern Nations: How Sensitive?”, in R. Faini and R. Portes (eds), European Union Trade with Eastern Europe: Adjustment and Opportunities (London: CEPR).

OECD (2002), OECD Economic Surveys: Russian Federation, Paris, February.

OECD (2004), OECD Economic Surveys: Russian Federation, Paris, September.

Senik-Leygonie, C. and Gordon, H. (1992), “The Break-up of the Soviet Union: Industrial Profitability and Trade among the Former Soviet Republics”, Economic Policy, Issue 15 (October). 
ANNEX. COMPETITIVENESS DATA

Figure A1. Value added per employee Thousand roubles per employee, 2002

$\begin{array}{llllll}0 & 200 & 400 & 600 & 800 & 1000\end{array}$

Fuel industry

Non-ferrous metallurgy

Electric power industry

Ferrous metallurgy

Food industry

Other industries

Chemical and petrochemical industry

Medical industry

Typographical industry Glass and ceramics industry

Building materials industry Logging, woodworking and pulp-and-paper industry Machine-building and metal working

Grain processing industry

Microbiological industry Light industry

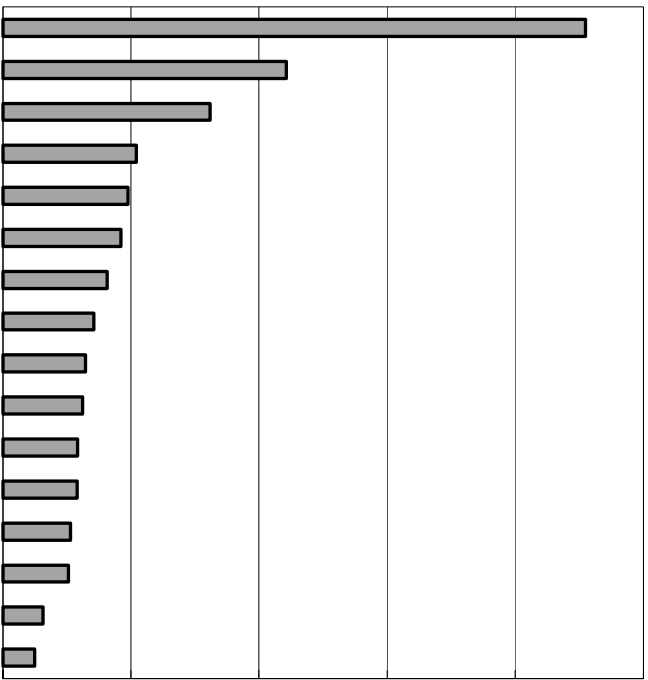

Source: Goskomstat and OECD calculations. 
Figure A2. Output and profits per employee by industrial sectors 2001

\section{A. Output per employee}

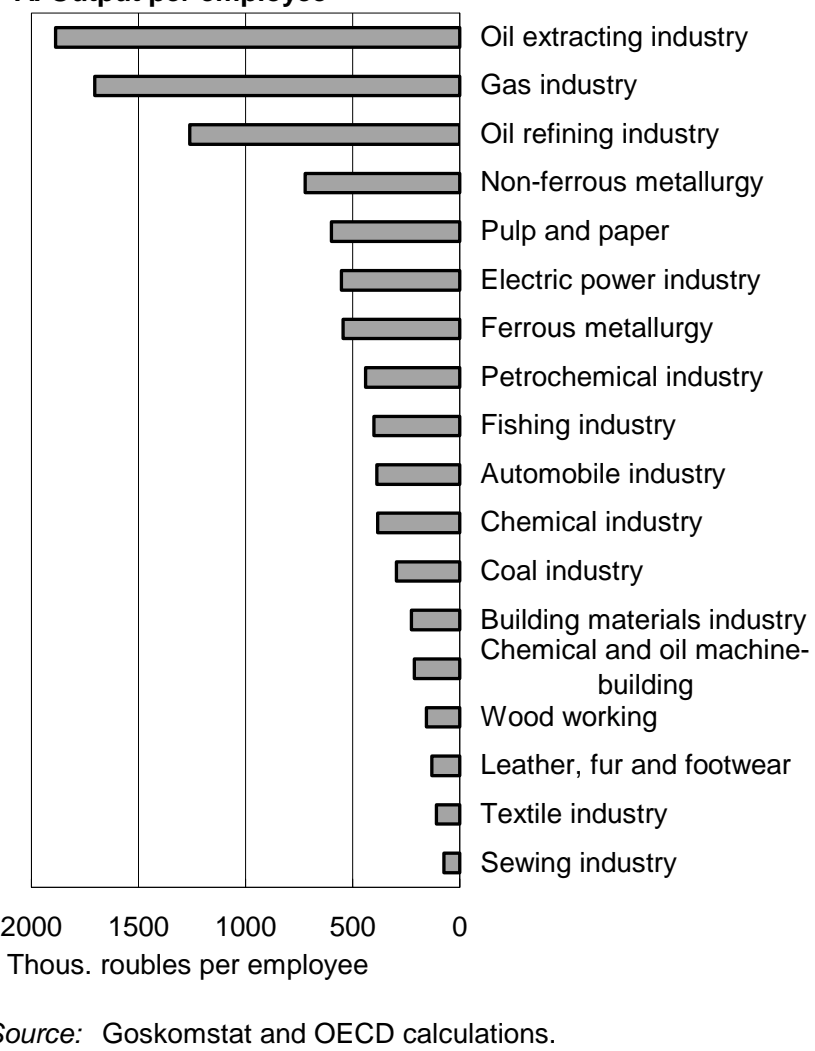

Source: Goskomstat and OECD calculations.

\section{B. Profits per employee}

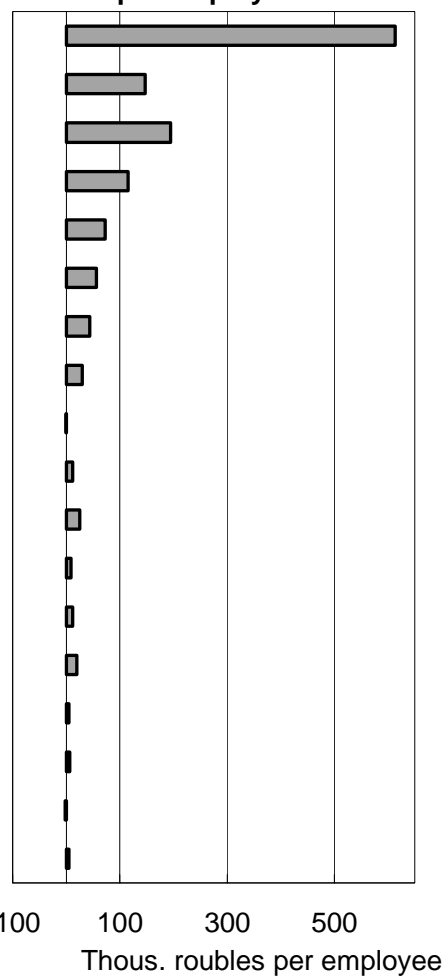


Figure A3. Initial profitability levels vs. productivity growth (by industrial sector)

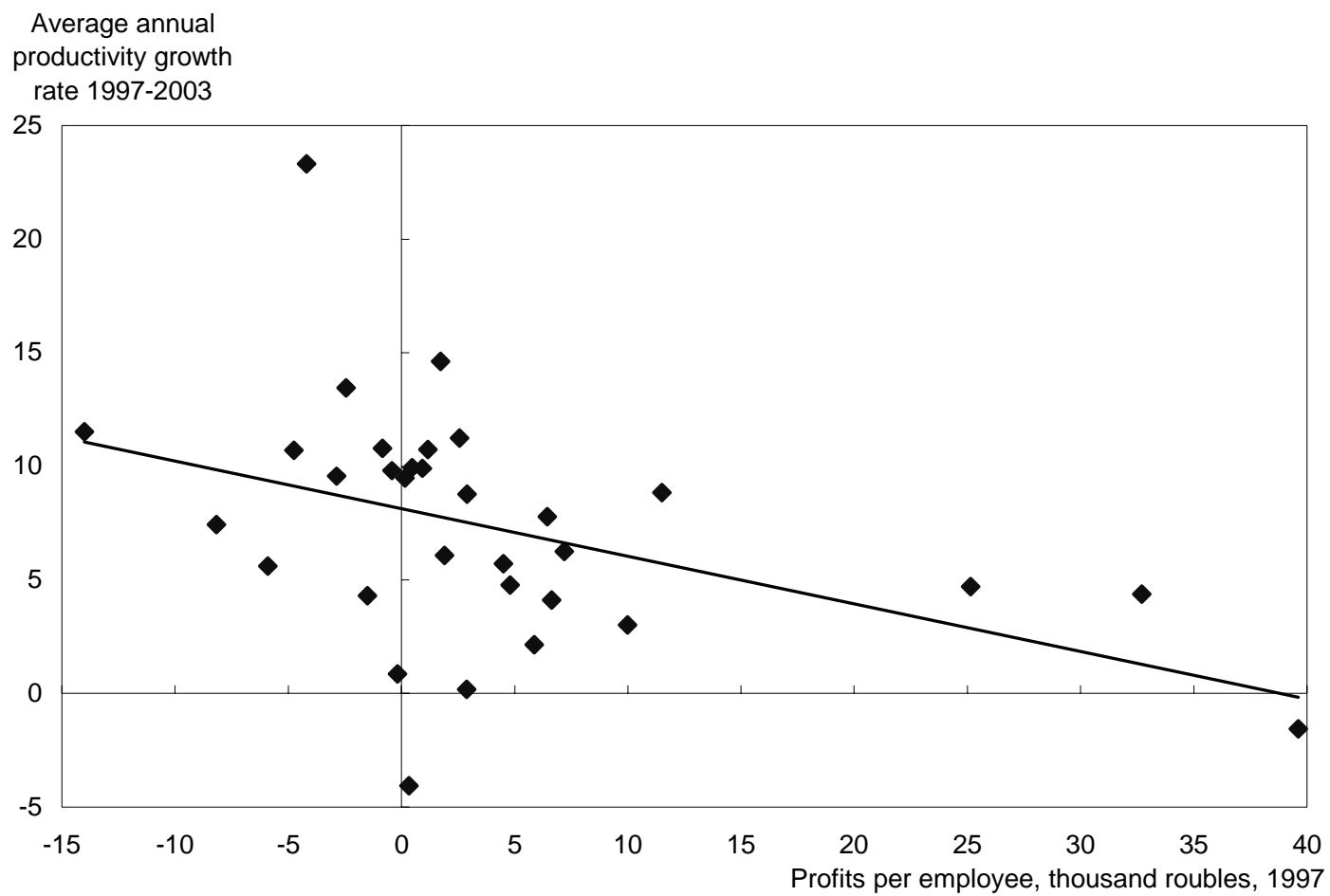

Source: Goskomstat and OECD calculations. 
Table A1. Labour productivity changes (30 large industrial sectors)

Annual percentage change

\begin{tabular}{|c|c|c|c|c|c|c|c|c|c|}
\hline & $\begin{array}{l}\text { Average } \\
1990-95\end{array}$ & 1996 & 1997 & 1998 & 1999 & 2000 & 2001 & 2002 & 2003 \\
\hline Total industry & -8.1 & 2.9 & 8.7 & 1.0 & 11.8 & 10.2 & 5.1 & 6.6 & 12.4 \\
\hline Electric power industry & -10.3 & -7.0 & -4.4 & -5.7 & -5.3 & -1.7 & -1.1 & -1.0 & 5.9 \\
\hline Oil extracting industry & -15.0 & -15.1 & -5.9 & -9.6 & 11.3 & 3.6 & -16.9 & -6.0 & 23.8 \\
\hline Oil refining industry & -11.0 & -10.5 & 0.7 & 0.7 & 8.3 & 2.0 & 4.9 & 4.7 & 7.8 \\
\hline Gas industry & -9.2 & -8.2 & -14.5 & -13.9 & -6.5 & -1.3 & -5.7 & -23.5 & 5.2 \\
\hline Coal industry & -4.2 & 7.3 & 9.0 & 10.0 & 20.5 & 10.5 & 6.2 & -3.6 & 17.0 \\
\hline Ferrous metallurgy & -8.6 & -2.0 & 7.5 & -6.6 & 16.5 & 10.3 & -2.4 & 1.1 & 20.4 \\
\hline Non-ferrous metallurgy & -13.4 & -1.9 & 12.1 & 1.6 & 5.0 & 3.3 & 1.0 & -2.1 & 9.7 \\
\hline Chemical industry & -11.0 & -5.3 & 6.4 & 3.0 & 28.3 & 10.0 & 5.1 & 3.4 & \\
\hline Petrochemical industry & -11.9 & -2.8 & 4.9 & -9.6 & 25.7 & 9.8 & 6.7 & -0.9 & \\
\hline Electronics & -15.7 & -7.6 & -6.9 & 0.7 & 12.5 & 32.9 & 19.2 & -6.5 & \\
\hline Chemical and oil machine-building & -9.3 & -22.8 & 19.6 & 3.2 & 2.7 & 33.6 & 3.1 & -16.3 & \\
\hline Automobile industry & -10.5 & 6.1 & 15.1 & -8.5 & 12.9 & 3.2 & 7.6 & -3.0 & \\
\hline Repair of machinery and equipment & -2.3 & -2.6 & -1.4 & 18.0 & 17.3 & 17.9 & -8.3 & 7.7 & \\
\hline Wood working & -15.4 & -16.4 & 4.8 & 6.6 & 9.4 & 5.4 & -0.1 & 0.6 & \\
\hline Pulp and paper & -11.3 & -16.6 & 8.2 & 0.3 & 21.4 & 5.7 & 26.6 & 5.9 & \\
\hline Building materials industry & -13.1 & -7.0 & 6.4 & 3.2 & 9.2 & 18.6 & 7.1 & 17.0 & 10.1 \\
\hline Glass and ceramics industry & -5.2 & -4.6 & 0.8 & 10.4 & 20.5 & 2.9 & 19.8 & 10.2 & 15.4 \\
\hline Textile industry & -21.0 & -14.1 & 17.1 & -15.8 & 37.5 & 28.0 & 22.2 & 3.8 & \\
\hline Sewing industry & -15.3 & 2.9 & 11.7 & 32.1 & -2.7 & 27.7 & 2.2 & -4.2 & \\
\hline Leather, fur and footwear & -23.3 & -15.2 & 1.6 & -3.7 & 38.6 & 8.5 & -0.5 & 9.3 & \\
\hline Bread industry & -10.0 & -15.3 & -9.0 & 4.8 & -0.3 & -7.2 & -3.7 & -3.0 & \\
\hline Confectionery industry & -12.8 & -4.0 & 13.2 & 13.6 & -7.4 & 6.9 & 9.0 & 4.7 & \\
\hline Brewing industry & -9.8 & -10.7 & 21.2 & 34.8 & -2.0 & 16.4 & 36.6 & 4.7 & \\
\hline Tobacco industry & 7.6 & -15.1 & 40.3 & 8.6 & 1.3 & 12.0 & 29.1 & 9.9 & \\
\hline Meat industry & -14.7 & -6.5 & -9.0 & -16.3 & 13.1 & 10.6 & 7.6 & 11.2 & \\
\hline Dairy industry & -15.9 & -7.5 & 0.9 & 14.7 & -13.2 & 7.5 & 13.1 & 4.7 & \\
\hline Fishing industry & -8.7 & 12.2 & 13.8 & 10.3 & 1.2 & 31.0 & -3.0 & 0.9 & \\
\hline Grain processing industry & -15.2 & -15.1 & 2.0 & -6.8 & 3.0 & -8.2 & 10.9 & -8.2 & 6.4 \\
\hline Medical industry & -7.4 & 10.1 & 27.5 & -4.7 & 38.6 & 3.6 & -4.3 & -1.4 & \\
\hline Typographical industry & 4.1 & 19.7 & -2.1 & 1.9 & -0.5 & 6.2 & 21.9 & -2.4 & -2.2 \\
\hline
\end{tabular}


Table A2. Decomposition of labour productivity (30 large industrial sectors)

Percentage change

\begin{tabular}{|c|c|c|c|c|c|c|}
\hline & \multicolumn{3}{|c|}{$1997-2002$} & \multicolumn{3}{|c|}{$1990-96$} \\
\hline & $\begin{array}{l}\text { Labour } \\
\text { productivity }\end{array}$ & Output & Employment & $\begin{array}{l}\text { Labour } \\
\text { productivity }\end{array}$ & Output & Employment \\
\hline Total industry & 39.4 & 28.6 & -7.8 & -33 & -52 & -29 \\
\hline Electric power industry & -14.1 & 0.2 & 16.7 & -46 & -22 & 45 \\
\hline Oil extracting industry & -18.5 & 24.0 & 52.3 & -62 & -32 & 80 \\
\hline Oil refining industry & 22.2 & 4.3 & -14.6 & -50 & -33 & 33 \\
\hline Gas industry & -42.6 & 8.7 & 89.4 & -43 & -14 & 52 \\
\hline Coal industry & 49.9 & 11.1 & -25.9 & -14 & -27 & -15 \\
\hline Ferrous metallurgy & 18.3 & 28.4 & 8.5 & -38 & -42 & -7 \\
\hline Non-ferrous metallurgy & 9.0 & 35.2 & 24.0 & -52 & -47 & 10 \\
\hline Chemical industry & 57.9 & 45.4 & -7.9 & -47 & -56 & -17 \\
\hline Petrochemical industry & 32.0 & 41.0 & 6.9 & -48 & -61 & -24 \\
\hline Electronics & 67.8 & 56.4 & -6.8 & -61 & -77 & -41 \\
\hline Chemical and oil machine-building & 22.3 & 54.5 & 26.3 & -53 & -67 & -31 \\
\hline Automobile industry & 11.2 & 5.8 & -4.9 & -39 & -50 & -18 \\
\hline Repair of machinery and equipment & 61.0 & 32.3 & -17.8 & -13 & -36 & -26 \\
\hline Wood working & 23.4 & 11.2 & -9.9 & -64 & -70 & -17 \\
\hline Pulp and paper & 72.5 & 76.9 & 2.5 & -54 & -60 & -13 \\
\hline Building materials industry & 67.6 & 27.6 & -23.9 & -54 & -63 & -21 \\
\hline Glass and ceramics industry & 80.7 & 66.7 & -7.8 & -27 & -42 & -21 \\
\hline Textile industry & 88.0 & 47.3 & -21.6 & -74 & -86 & -48 \\
\hline Sewing industry & 60.7 & 22.4 & -23.8 & -55 & -81 & -57 \\
\hline Leather, fur and footwear & 57.3 & 12.0 & -28.8 & -77 & -86 & -39 \\
\hline Bread industry & -9.5 & -6.3 & 3.5 & -50 & -49 & 3 \\
\hline Confectionery industry & 28.2 & 41.5 & 10.3 & -52 & -53 & -2 \\
\hline Brewing industry & 119.7 & 157.7 & 17.3 & -47 & -41 & 11 \\
\hline Tobacco industry & 74.8 & 126.2 & 29.4 & 22 & 31 & 7 \\
\hline Meat industry & 25.2 & 9.7 & -12.3 & -58 & -62 & -9 \\
\hline Dairy industry & 26.6 & 40.5 & 11.0 & -61 & -65 & -10 \\
\hline Fishing industry & 43.0 & 11.8 & -21.8 & -29 & -40 & -16 \\
\hline Grain processing industry & -10.3 & 0.2 & 11.7 & -63 & -57 & 15 \\
\hline Medical industry & 29.0 & 52.0 & 17.9 & -25 & -15 & 13 \\
\hline Typographical industry & 27.9 & 43.1 & 11.8 & 46 & 14 & -22 \\
\hline
\end{tabular}

Source: Goskomstat and OECD calculations. 


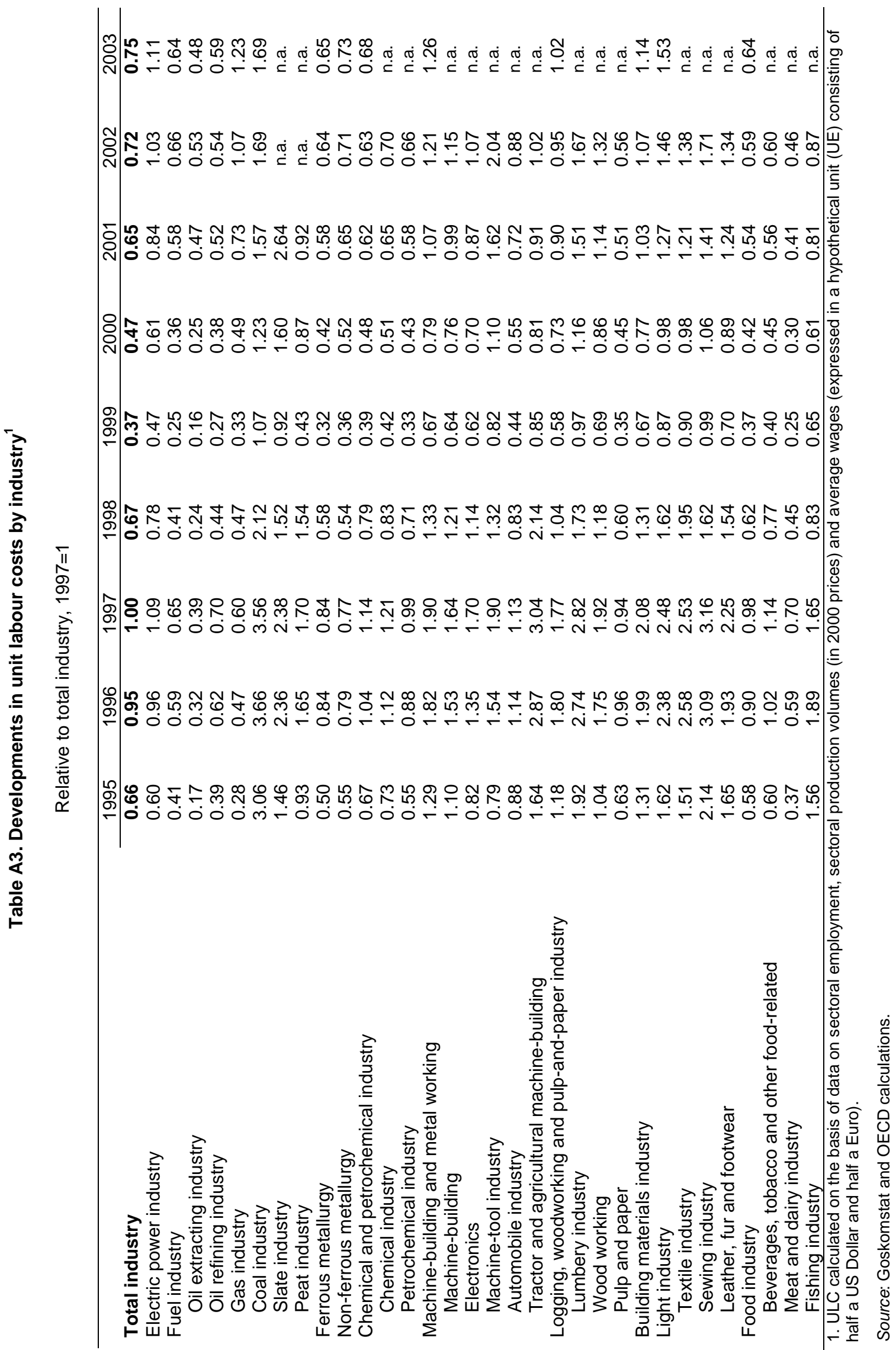


Figure A4. Initial unit labour costs vs. changes in employment and wages

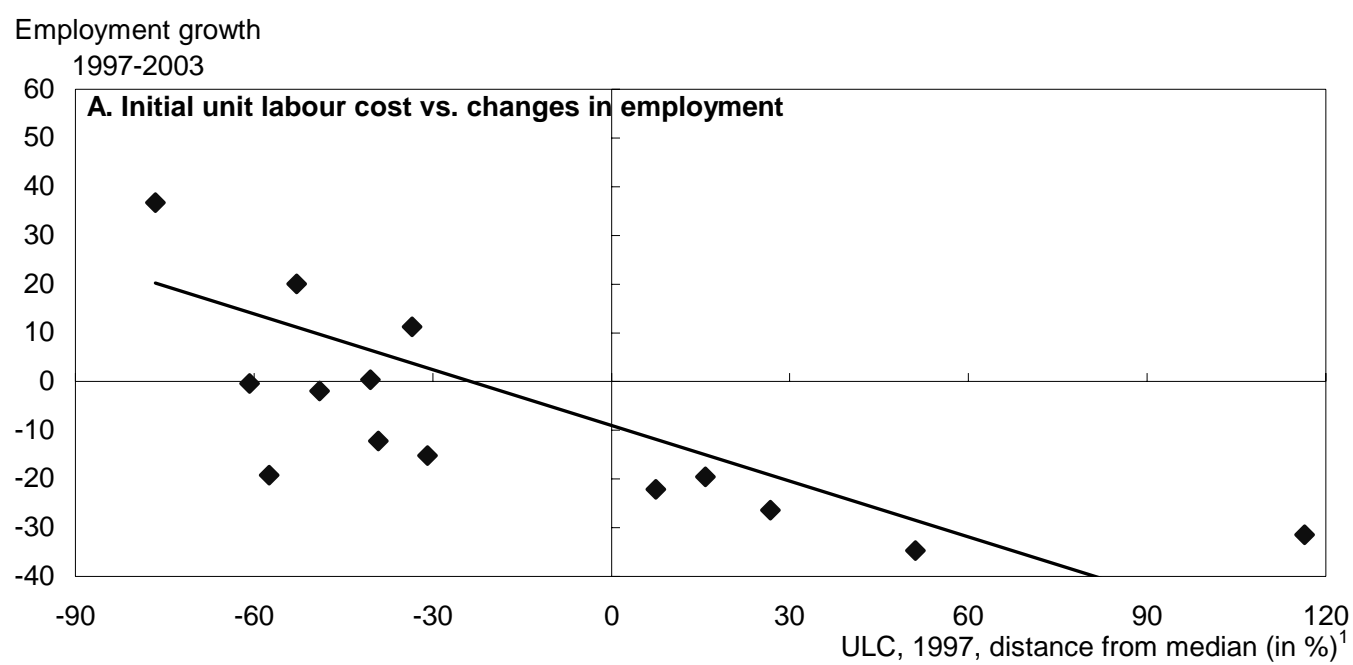

Wage growth 1997-

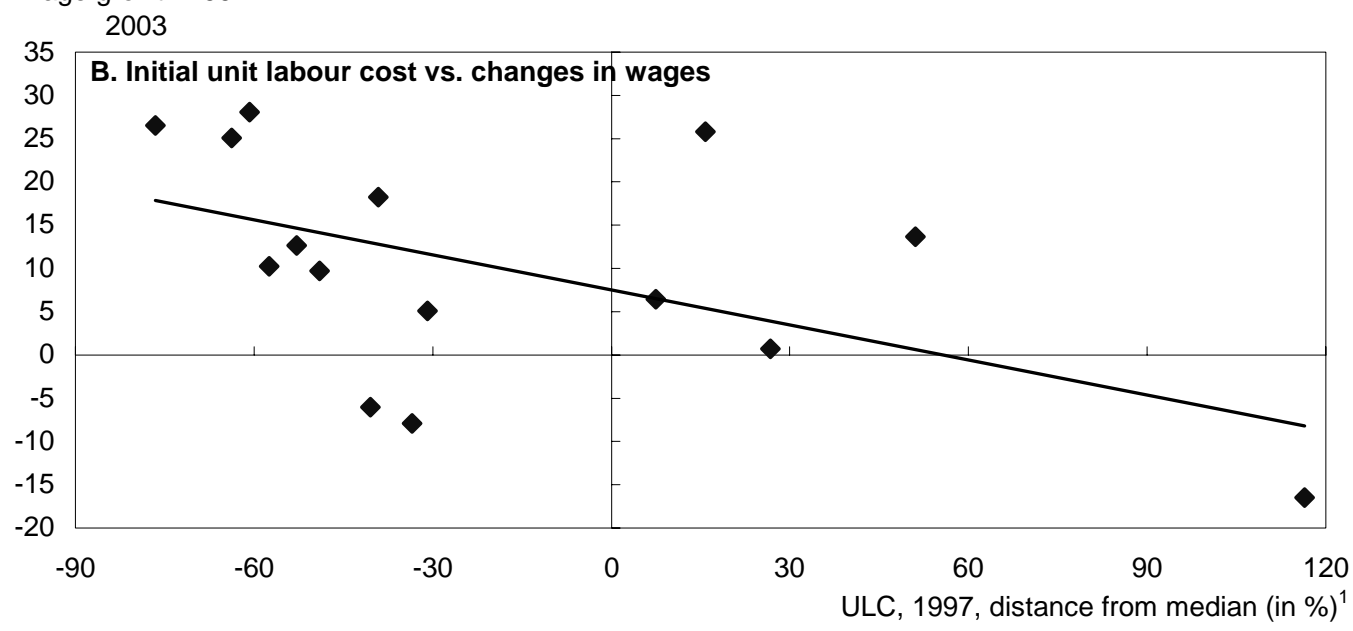

1. ULC calculated on the basis of data on sectoral employment, sectoral production volumes (in 2000 prices) and average wages (expressed in a hypothetical unit (UE) consisting of half a US Dollar and half a Euro). Source: Goskomstat and OECD calculations. 
ECO/WKP(2004)31

Table A4. Detailed structure of exports, 2003

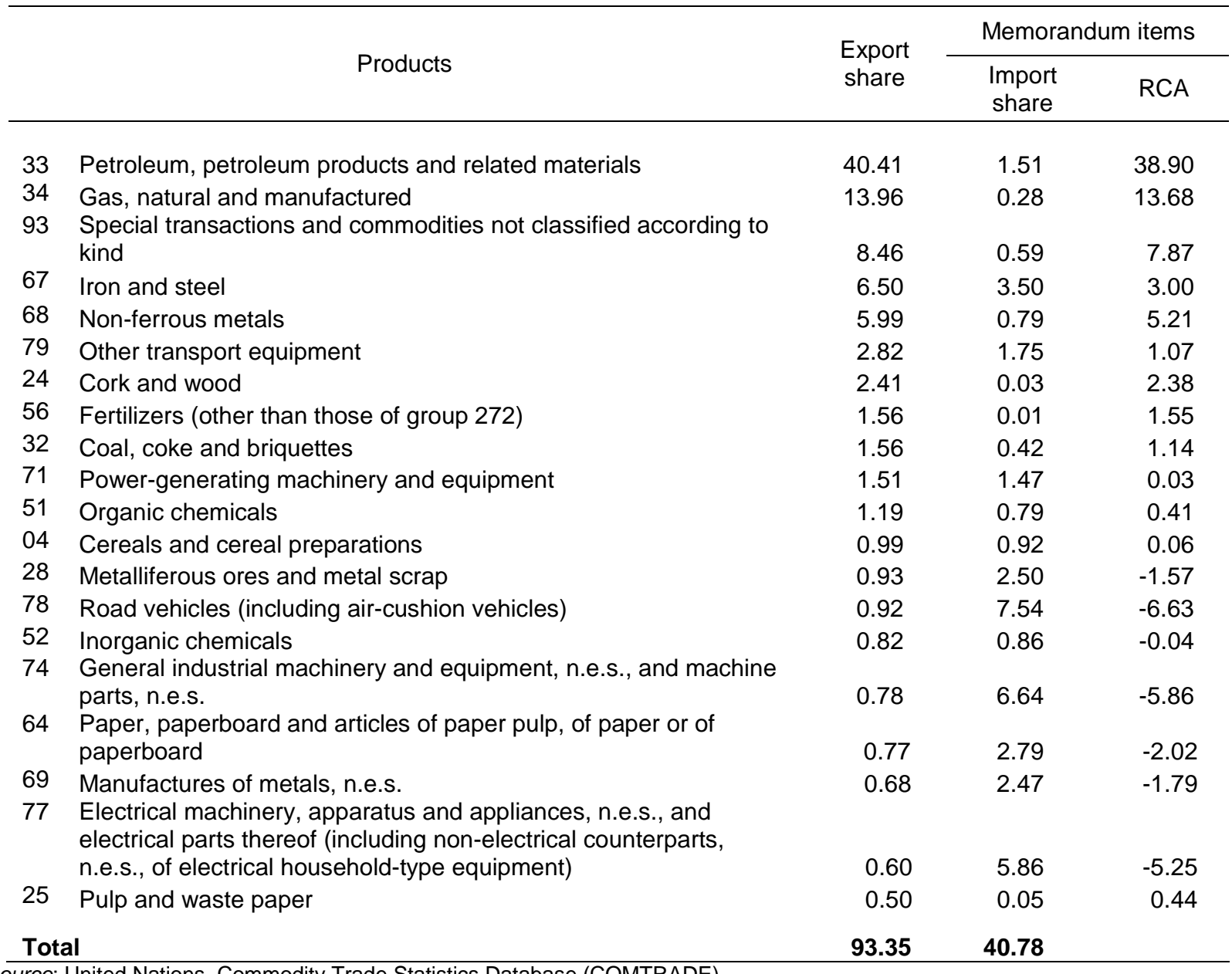

Source: United Nations, Commodity Trade Statistics Database (COMTRADE). 
Table A5. Detailed structure of imports, 2003

\begin{tabular}{|c|c|c|c|c|}
\hline & \multirow{2}{*}{ Products } & \multirow[b]{2}{*}{$\begin{array}{l}\text { Import } \\
\text { share }\end{array}$} & \multicolumn{2}{|c|}{$\begin{array}{c}\text { Memorandum } \\
\text { items }\end{array}$} \\
\hline & & & $\begin{array}{l}\text { Export } \\
\text { share }\end{array}$ & $\mathrm{RCA}$ \\
\hline \multirow{2}{*}{$\begin{array}{l}78 \\
74\end{array}$} & Road vehicles (including air-cushion vehicles) & 7.54 & 0.92 & -6.63 \\
\hline & $\begin{array}{l}\text { General industrial machinery and equipment, n.e.s., and machine } \\
\text { parts, n.e.s. }\end{array}$ & 6.64 & 0.78 & -5.86 \\
\hline 77 & $\begin{array}{l}\text { Electrical machinery, apparatus and appliances, n.e.s., and } \\
\text { electrical parts thereof (including non-electrical counterparts, n.e.s., } \\
\text { of electrical household-type equipment) }\end{array}$ & 5.86 & 0.60 & -5.25 \\
\hline 72 & Machinery specialized for particular industries & 5.19 & 0.34 & -4.85 \\
\hline 54 & Medicinal and pharmaceutical products & 4.52 & 0.16 & -4.36 \\
\hline 01 & Meat and meat preparations & 4.16 & 0.02 & -4.14 \\
\hline 05 & Vegetables and fruit & 3.98 & 0.10 & -3.87 \\
\hline 76 & $\begin{array}{l}\text { Telecommunications and sound-recording and reproducing } \\
\text { apparatus and equipment }\end{array}$ & 3.60 & 0.23 & -3.37 \\
\hline 67 & Iron and steel & 3.50 & 6.50 & 3.00 \\
\hline 89 & Miscellaneous manufactured articles, n.e.s. & 3.16 & 0.47 & -2.69 \\
\hline 64 & $\begin{array}{l}\text { Paper, paperboard and articles of paper pulp, of paper or of } \\
\text { paperboard }\end{array}$ & 2.79 & 0.77 & -2.02 \\
\hline 28 & Metalliferous ores and metal scrap & 2.50 & 0.93 & -1.57 \\
\hline 69 & Manufactures of metals, n.e.s. & 2.47 & 0.68 & -1.79 \\
\hline 87 & $\begin{array}{l}\text { Professional, scientific and controlling instruments and apparatus, } \\
\text { n.e.s. }\end{array}$ & 2.26 & 0.46 & -1.81 \\
\hline 55 & $\begin{array}{l}\text { Essential oils and resinoids and perfume materials; toilet, polishing } \\
\text { and cleansing preparations }\end{array}$ & 2.18 & 0.19 & -2.00 \\
\hline 06 & Sugars, sugar preparations and honey & 1.99 & 0.05 & -1.94 \\
\hline 07 & Coffee, tea, cocoa, spices, and manufactures thereof & 1.91 & 0.10 & -1.82 \\
\hline 65 & Textile yarn, fabrics, made-up articles, n.e.s., and related products & 1.90 & 0.31 & -1.59 \\
\hline 79 & Other transport equipment & 1.75 & 2.82 & 1.07 \\
\hline 11 & Beverages & 1.72 & 0.11 & -1.61 \\
\hline \multicolumn{2}{|c|}{ Total } & 69.62 & 16.54 & \\
\hline
\end{tabular}


ECO/WKP(2004)31

Table A6. Changes in revealed comparative advantage, 1997-2003

\begin{tabular}{|c|c|c|c|c|}
\hline \multirow{2}{*}{$\begin{array}{l}\text { SITC } \\
\operatorname{Rev} 3\end{array}$} & \multirow{2}{*}{ Title } & \multicolumn{2}{|c|}{ RCA } & \multirow{2}{*}{ Difference } \\
\hline & & 2003 & 1997 & \\
\hline \multicolumn{5}{|c|}{10 largest positive changes } \\
\hline 33 & Petroleum, petroleum products and related materials & 38.90 & 23.76 & 15.14 \\
\hline 79 & Other transport equipment & 1.07 & -1.30 & 2.37 \\
\hline 04 & Cereals and cereal preparations & 0.06 & -1.42 & 1.48 \\
\hline 32 & Coal, coke and briquettes & 1.14 & 0.68 & 0.45 \\
\hline 24 & Cork and wood & 2.38 & 1.96 & 0.42 \\
\hline 12 & Tobacco and tobacco manufactures & -1.34 & -1.64 & 0.30 \\
\hline 09 & Miscellaneous edible products and preparations & -0.82 & -1.00 & 0.17 \\
\hline 61 & Leather, leather manufactures, n.e.s., and dressed fur skins & 0.05 & -0.02 & 0.07 \\
\hline 25 & Pulp and waste paper & 0.44 & 0.39 & 0.06 \\
\hline 82 & $\begin{array}{l}\text { Furniture, and parts thereof; bedding, mattresses, mattress } \\
\text { supports, cushions and similar stuffed furnishings }\end{array}$ & -0.66 & -0.72 & 0.06 \\
\hline \multicolumn{5}{|c|}{10 largest negative changes } \\
\hline 34 & Gas, natural and manufactured & 13.68 & 18.27 & -4.59 \\
\hline 78 & Road vehicles (including air-cushion vehicles) & -6.63 & -2.49 & -4.14 \\
\hline 77 & $\begin{array}{l}\text { Electrical machinery, apparatus and appliances, n.e.s., and } \\
\text { electrical parts thereof (including non-electrical counterparts, } \\
\text { n.e.s., of electrical household-type equipment) }\end{array}$ & -5.25 & -2.20 & -3.05 \\
\hline 68 & Non-ferrous metals & 5.21 & 8.26 & -3.05 \\
\hline 67 & Iron and steel & 3.00 & 5.67 & -2.67 \\
\hline 54 & Medicinal and pharmaceutical products & -4.36 & -2.53 & -1.83 \\
\hline 28 & Metalliferous ores and metal scrap & -1.57 & -0.05 & -1.52 \\
\hline 72 & Machinery specialized for particular industries & -4.85 & -3.40 & -1.45 \\
\hline 89 & Miscellaneous manufactured articles, n.e.s. & -2.69 & -1.25 & -1.44 \\
\hline 64 & $\begin{array}{l}\text { Paper, paperboard and articles of paper pulp, of paper or of } \\
\text { paperboard }\end{array}$ & -2.02 & -0.64 & -1.39 \\
\hline
\end{tabular}

Note: RCA changes of the "non-classified" items category are not reported in this table.

Source: United Nations, Commodity Trade Statistics Database (COMTRADE). 
Table A7. Import competition

Percentage of surveyed enterprises (by industrial sector) that mention this factor

\begin{tabular}{|c|c|c|c|c|c|c|c|c|}
\hline & 1996 & 1997 & 1998 & 1999 & 2000 & 2001 & 2002 & 2003 \\
\hline \multicolumn{9}{|c|}{ Importance of increasing volumes of imports as a factor that increases competition } \\
\hline Metallurgy & 3 & 13 & 24 & 7 & 17 & 14 & 24 & 19 \\
\hline Chemical and petrochemical industry & 20 & 22 & 25 & 14 & 13 & 11 & 26 & 29 \\
\hline Machine building & 26 & 28 & 29 & 8 & 7 & 16 & 24 & 31 \\
\hline Forestry, pulp and paper & 40 & 19 & 27 & 1 & 5 & 22 & 24 & 16 \\
\hline Building materials & 30 & 3 & 13 & 0 & 1 & 4 & 9 & 7 \\
\hline Light industry & 50 & 54 & 37 & 6 & 9 & 29 & 32 & 42 \\
\hline Food industry & 41 & 25 & 32 & 12 & 14 & 16 & 8 & 23 \\
\hline \multicolumn{9}{|c|}{ Importance of low import prices as a factor that increases competition } \\
\hline Metallurgy & 0 & 11 & 36 & 12 & 23 & 6 & 10 & 20 \\
\hline Chemical and petrochemical industry & 30 & 15 & 21 & 3 & 16 & 21 & 21 & 27 \\
\hline Machine building & 10 & 14 & 8 & 2 & 5 & 13 & 12 & 22 \\
\hline Forestry, pulp and paper & 13 & 15 & 10 & 1 & 3 & 1 & 5 & 10 \\
\hline Building materials & 14 & 4 & 9 & 1 & 8 & 4 & 2 & 3 \\
\hline Light industry & 24 & 28 & 31 & 14 & 13 & 29 & 33 & 34 \\
\hline Food industry & 38 & 35 & 34 & 22 & 15 & 7 & 8 & 12 \\
\hline
\end{tabular}

Importance of better quality of imports as a factor that increases competition

\begin{tabular}{|c|c|c|c|c|c|c|c|c|}
\hline Metallurgy & 1 & 0 & 6 & 1 & 9 & 10 & 11 & 7 \\
\hline Chemical and petrochemical industry & 1 & 2 & 12 & 10 & 20 & 7 & 11 & 27 \\
\hline Machine building & 9 & 18 & 14 & 8 & 19 & 17 & 27 & 24 \\
\hline Forestry, pulp and paper & 12 & 18 & 26 & 20 & 11 & 6 & 10 & 16 \\
\hline Building materials & 11 & 1 & 6 & 3 & 13 & 10 & 8 & 7 \\
\hline Light industry & 4 & 5 & 3 & 7 & 6 & 11 & 8 & 9 \\
\hline Food industry & 1 & 0 & 1 & 2 & 0 & 0 & 2 & 1 \\
\hline
\end{tabular}




\section{WORKING PAPERS}

The full series of Economics Department Working Papers can be consulted at www.oecd.org/eco/Working_Papers/

407. Improving the Capacity to Innovate in Germany (October 2004) Andrés Fuentes, Eckhard Wurzel and Margaret Morgan

406. Tax Treatment of Private Pension Savings in OECD Countries and the Net Tax Cost per Unit of Contribution to Tax-Favoured Schemes

(October 2004) Kwang-Yeol Yoo and Alain de Serres

405. The Reform of the Health Care System in Portugal (October 2004) Stéphanie Guichard

404. Accounting for Russia's Post-Crisis Growth (October 2004) Rudiger Ahrend

403. Restructuring Russia's Electricity Sector: Towards Effective Competition or Faux Liberalisation? (October 2004) William Tompson

402. Russia's Gas Sector: The Endless Wait for Reform? (September 2004) Rudiger Ahrend and William Tompson

401. One Money, One Cycle? Making Monetary Union a Smoother Ride (September 2004) Peter Hoeller, Claude Giorno and Christine de la Maisonneuve

400. Modelling Cyclical Divergence in the Euro Area: The Housing Channel (September 2004) Paul van den Noord

399. Product Market Competition and Economic Performance in Korea (August 2004) Yongchun Baek, Randall Jones and Michael Wise

398. Product Market Competition and Economic Performance in the United States (July 2004) Hannes Suppanz, Michael Wise and Michael Kiley

397. Saving Behaviour and the Effectiveness of Fiscal Policy (July 2004) Luiz de Mello, Per Mathis Kongsrud and Robert Price

396. The impact of exchange rate regimes on real exchange rates in South America, 1990-2002 (June 2004) Anne-Laure Baldi and Nanno Mulder

395. How Market Imperfections and Trade Barriers Shape Specialisation: South America vs. OECD (June 2004) Joaquim Oliveira Martins and Tristan Price

394. Housing Markets, Wealth and the Business Cycle (June 2004) Pietro Catte, Nathalie Girouard, Robert Price and Christophe André

393. Long-Term Budgetary Implications of Tax-Favoured Retirement Saving Plans (June 2004) Pablo Antolin, Alain de Serres and Christine de la Maisonneuve

392. Enhancing Income Convergence in Central Europe after EU Accession (June 2004) Patrick Lenain and Lukasz Rawdanowicz

391. Asset Price Cycles, “One-Off” Factors and Structural Budget Balances (June 2004) Nathalie Girouard and Robert Price 


\section{ECO/WKP(2004)31}

390. Channels for Narrowing the US Current Account Deficit and Implications for Other Economies (May 2004) Anne-Marie Brook, Franck Sédillot and Patrice Ollivaud

389. Product Market Competition and Economic Performance in Norway (May 2004) Jens Høj and Michael Wise.

388. Product Market Competition and Economic Performance in Sweden (May 2004) Deborah Roseveare, Martin Jørgensen and Lennart Goranson

387. Product Market Competition and Economic Performance in Japan (May 2004) Jens Høj and Michael Wise

386. Migration and Integration of Immigrants in Denmark (May 2004) Deborah Roseveare and Martin Jørgensen

385. Factors Driving Risk Premia (April 2004) Torsten Sløk and Mike Kennedy

384. Rationalising Public Expenditure in the Slovak Republic (March 2004) Rauf Gönenç and Peter Walkenhorst

383. Product Market Competition and Economic Performance in Switzerland (March 2004) Claude Giorno, Miguel Jimenez and Philippe Gugler

383. Concurrence sur les Marchés de Produits et Performance Économique en Suisse (Mars 2004) Claude Giorno, Miguel Jimenez and Philippe Gugler

382. Differences in Resilience between the Euro-Area and US Economies (March 2004) Aaron Drew, Mike Kennedy and Torsten Sløk

381. Product Market Competition and Economic Performance in Hungary (March 2004) Carl Gjersem, Philip Hemmings and Andreas Reindl

380. Enhancing the Effectiveness of Public Spending: Experience in OECD Countries (February 2004) Isabelle Joumard, Per Mathis Kongsrud, Young-Sook Nam and Robert Price

379. Is there a Change in the Trade-Off between Output and Inflation at Low or Stable Inflation Rates? Some Evidence in the Case of Japan (February 2004) Annabelle Mourougane and Hideyuki Ibaragi

378. Policies bearing on product market competition and growth in Europe (January 2004) Carl Gjersem

377. Reforming the Public Expenditure System in Korea (December 2003) Young-Sook Nam and Randall Jones

376. Female Labour Force Participation: Past Trends and Main Determinants in OECD Countries (December 2003) Florence Jaumotte

375. Fiscal Relations Across Government Levels (December 2003) Isabelle Joumard and Per Mathis Kongsrud

374. Health-Care Systems: Lessons from the Reform Experience (December 2003) Elizabeth Docteur and Howard Oxley 